\title{
NASIB TKI DI TENGAH KEBERADAAN UNDANG-UNDANG NOMOR 39 TAHUN 2004
}

\author{
Mustika Prabaningrum Kusumawati \\ Fakultas Hukum Universitas Islam Indonesia \\ Dosen Hukum Adiministrasi Negara (HAN) \\ Email: mustika.praba@gmail.com
}

\begin{abstract}
ABSTRAK
Nasib TKI di tengah keberadaan Undang-Undang Nomor 39 Tahun 2004 tentang Penempatan dan Perlindungan TKI di Luar Negeri nampaknya masih menyisakan tanda tanya akan kapabilitasnya apabila melihat kenyataan bahwa masih maraknya TKI yang mendapatkan perlakuan buruk atau penyiksaan di negeri orang. Faktor-faktor penyebab terjadinya penyiksaan ini dilatarbelakangi oleh sempitnya lapangan pekerjaan yang ada di Indonesia yang menyebabkan ledakan minat masyarakat untuk menjadi TKI dan menjadi parah ketika sebagian besar dari mereka memilih untuk menjadi TKI melalui jalur illegal. Faktor pemicu lainnya ialah rendahnya kualitas SDM dan rendahnya pendidikan TKI kita. Untuk menjamin perlindungan hukum dalam penempatan TKI (tenaga kerja Indonesia) di luar negeri, maka pemerintah telah mengakomodir Undang-Undang Nomor 39 Tahun 2004 tentang Penempatan dan Perlindungan Tenaga Kerja Indonesia di Luar Negeri. Akan tetapi kenyataannya, nasib TKI (Tenaga Kerja Indonesia) di negeri orang berbanding terbalik dengan apa yang telah dijamin oleh keberadaan UndangUndang Nomor 39 Tahun 2004 tentang Penempatan dan Perlindungan Tenaga Kerja Indonesia di Luar Negeri. Peranan Undang-Undang Nomor 39 Tahun 2004 tentang Penempatan dan Perlindungan TKI di Luar Negeri dalam memberikan jaminan perlindungan bagi TKI dirasa masih kurang mampu dalam mengakomodir perlindungan hukum bagi TKI. Oleh sebab itulah sangat dibutuhkan tidak hanya peranan dari pemerintah saja tetapi juga peranan dari TKI itu sendiri dalam membekali diirinya dalam hal pengetahuan dan skill agar terhindar dari berbagai bentuk perlakuan buruk di negeri orang.
\end{abstract}

Kata Kunci: Undang-Undang Nomor 39 Tahun 2004, Perlindungan, Tenaga Kerja Indonesia

\section{ABSTRACT}

The fate of Indonesian Workers among the existence of Act No. 39 of 2004 concerning the Placement and Protection of Indonesian Workers Abroad seems remaining questions on its capability for there are still many cases of immoral treatment and violence. The factors of that treatment and violence are due to little job opportunities provided in Indonesia which then arise the society' interest to be Indonesian Workers, and this has been getting worse when most of them choose to be Indonesian Workers illegally. Another triggering factor is the low quality of Human Resources and education of the workers. In order to grant the legal protection in the placement of Indonesian Workers Abroad, the government has promulgated the Act No. 39 of 2004 concerning the Placement and Protection of Indonesian Workers Abroad. However, in fact, the Act No. 39 of 2004 concerning the Placement and 
Protection of Indonesian Workers Abroad is in contrast to the fate of Indonesian Workers Abroad. The role of the Act No. 39 of 2004 concerning the Placement and Protection of Indonesian Workers Abroad in granting the protection towards Indonesian Workers is still incapable to accommodate legal protection towards Indonesian Workers. Therefore, it requires not only the role of the government but also the Indonesian Workers themselves in preparing their knowledge and skill to avoid any immoral treatments abroad.

Keywords: The Act No. 39 of 2004, Protection, Indonesian Workers

\section{A. PENDAHULUAN}

Pada zaman era globalisasi seperti sekarang ini, kita sebagai manusia mempunyai berbagai macam kebutuhan baik sandang, pangan, dan papan ditambah lagi kebutuhan sekunder lainnya. Mengingat kebutuhan manusia yang semakin banyak dan berkembang serta mengingat harga-harga yang semakin mahal, seseorang rela untuk bekerja apa saja demi mendapatkan uang untuk memenuhi kebutuhan hidupnya yang salah satunya yaitu dengan menjadi Tenaga Kerja Indonesia (TKI).

Adanya faktor penghasilan yang lebih tinggi berkali lipat dibanding dengan penghasilan di dalam negeri tentunya menjadi faktor pemicu yang sangat menggiurkan bagi tenaga kerja kita. Banyak warga negara Indonesia tercinta yang bekerja di luar negeri sebagai TKI atau sebutan bijaknya adalah "Pahlawan Devisa". Namun, sebutan itu pada kenyataannya tidak sepadan dengan apa yang mereka alami. Banyak perlakuan buruk yang dialami oleh para TKI, baik pada saat mereka bekerja di sana atau bahkan pada saat mereka masih di Indonesia.

Istilah "Pahlawan Devisa" yang saat ini dirasa tidak sebanding dengan kenyataan yang dialami oleh para TKI kita. Sering sekali kita melihat serta mendengar berita yang menimpa TKI mulai dari penyiksaan fisik ringan, sedang, berat, bahkan tidak sedikit pula yang meregang nyawa di negeri orang. Masalah yang menimpa para TKI merupakan buntut dari kurangnya kualitas tenaga kerja kita. Barulah di saat-saat genting seperti ini semua pihak tidak terkecuali, menekan pemerintah agar mengambil sikap tegas agar para TKI mendapatkan perlindungan akan hak-haknya.

Maraknya kasus penyiksaan TKI seperti kasus Nirmala Bonat, Ceriyati, dan Siti Hajar yang telah nyata diungkap media massa serta diyakini masih banyak sekali kasus penyiksaan TKI yang belum terungkap, menjadi fakta menarik untuk dikaji lebih lanjut. Terlebih lagi dengan keberadaan Undang-Undang Nomor 39 Tahun 2004 tentang Penempatan dan Perlindungan Tenaga Kerja Indonesia di Luar Negeri. Pertanyaan besar pun muncul sebagai berikut:

1. Bagaimanakah nasib para TKI di negeri orang di tengah keberadaan UndangUndang Nomor 34 Tahun 2004 tentang Penempatan dan Perlindungan Tenaga Kerja Indonesia di Luar Negeri?

2. Seberapa besarkah peranan keberadaaan undang-undang ini dalam melindungi para TKI kita di luar negeri. 


\section{B. METODE PENELITIAN}

Untuk penelitian ilmu hukum normatif yang dikaji adalah bahan hukum yang berisi aturan-aturan yang bersifat normatif: Pertama, bahan hukum primer, khususnya peraturan-peraturan perundang-undangan; Kedua, bahan hukum sekunder, yang terdiri dari buku, jurnal, laporan penelitian, artikel ilmiah hukum dan sosial, serta bahan seminar, lokakarya, dan sebagainya. Bahan-bahan hukum yang diperoleh akan dianalisis dengan cara deskriptif kualitatif, khususnya dalam mencari latar belakang atau faktor utama yang menjadi penyebab TKI mendapatkan perlakuan buruk di negeri orang di tengah keberadaan Undang-Undang Nomor 39 Tahun 2004 tentang Penempatan dan Perlindungan TKI di Luar Negeri dalam memberikan jaminan perlindungan bagi TKI (tenaga kerja Indonesia).

\section{PEMBAHASAN}

1. Nasib TKI di Tengah Keberadaan Undang-Undang Nomor 34 Tahun 2004 tentang Penempatan dan Perlindungan Tenaga Kerja Indonesia di Luar Negeri

Fenomena global yang terjadi di hampir sebagian besar negara di dunia antara lain berupa migrasi internasional (termasuk migrasi tenaga kerja). Fenomena ini terus berkembang seiring dengan pola hubungan yang terjalin antarnegara dalam berbagai dimensi. Meningkatnya hubungan antarnegara pada gilirannya berpengaruh pada intensitas arus migrasi dari dan ke negara bersangkutan (Saleh, 2005: vii).

Perhatian publik tertuju pada angkatan kerja yang semakin "membludak" yang berbanding terbalik dengan ketersediaan lapangan pekerjaan yang ada. Permasalahan ini juga dapat dibahas dengan lebih lengkap apabila diperhatikan juga tingkat partisipasi pemuda-pemudi. Tingkat partisipasi pemuda kota di Indonesia termasuk sangat rendah apabila dibandingkan dengan beberapa negara lain, dan apabila dijumlahkan pemuda di luar angkatan kerja dan penganggur, nampaknya underutilization pemuda kota merupakan masalah serius yang memerlukan perhatian khusus. Peranan penting dari sektor informal di dalam penyerapan tenaga kerja di Indonesia dan di berbagai negara berkembang lainnya pun telah dikemukakan di dalam berbagai tulisan baik oleh sarjana-sarjana Indonesia maupun oleh sarjana luar negeri.

Tenaga kerja merupakan faktor yang terpenting dalam proses produksi. Sebagai suatu sarana produksi, tenaga kerja lebih diutamakan dibandingkan sarana produksi kerja lainnya seperti bahan mentah, tanah, air dan sebagainya. Karena manusialah yang menggerakkan semua sumber-sumber tersebut untuk menghasilkan barang (Bakir dan Manning, 1984: 149).

Ketika seseorang bekerja, motivasi bekerja sangat dipengaruhi oleh faktor internal dan faktor eksternal pekerja. Maksud faktor internal adalah segala sesuatu yang terdapat dalam diri atau keluarga yang menjadi pendorong untuk bekerja. Sedangkan faktor eksternal merupakan hal-hal yang terjadi di luar (khususnya di pasar kerja) yang menarik untuk bekerja (Usman dan Djalal, 2004: 79). 
Memperhatikan distribusi angkatan kerja di negara-negara maju saat ini terlihat bahwa proporsi terbesar berada pada sektor sekunder dan tersier. Hanya sebagian kecil saja di sektor primer (pertanian). Proses perkembangan ekonomi negara maju diikuti oleh suatu perubahan struktur kesempatan kerja sektor industri. Melihat pada dinamika struktur kesempatan kerja ini, Fisher dan Clark menyatakan bahwa dengan adanya kemajuan ekonomi suatu masyarakat jumlah angkatan kerja sektor primer cenderung lebih menurun dibanding dengan sektor sekunder yang selanjutnya sektor sekunder akan lebih menurun dibanding dengan sektor tersier (United Nations: 61-63).

Perkembangan penduduk Indonesia yang cepat akan diikuti pula dengan perkembangan jumlah angkatan kerja yang pesat pula. Sejumlah angkatan kerja muda akan memasuki pasar kerja untuk mendapatkan pekerjaan yang sesuai dan keadaan ini akan terus berlangsung secara terus menerus (Bakir dan Manning, 1984: 149).

Tjandraningsih menyebutkan bahwa di sentra-sentra industri kecil pedesaan yang berlokasi di tengah pemukiman penduduk, dengan tempat kerja yang menyatu dengan rumah, secara langsung maupun tidak langsung mendorong anak-anak untuk ikut dalam kegiatan industri sebagai pekerja, baik sebagai buruh maupun sebagai pekerja keluarga atau tenaga magang (Tjandraningsih, 1997: 41-46).

Keunggulan di dalam sebuah persaingan di era globalisasi saat ini sangatlah bergantung kepada kualitas sumber daya manusia (SDM) yang tentunya berperan di dalam penguasaan dan penerapan teknologi. Kualitas yang dibutuhkan adalah yang dapat memenuhi standar kompetensi internasional.

Situasi dan permasalahan ketenagakerjaan yang dihadapi Indonesia antara lain adalah kualitas sumber daya manusia (SDM) yang sangat rendah, tingkat pengangguran dan setengah pengangguran yang tinggi serta tingkat kesejahteraan sosial yang rendah yang dilatarbelakangi oleh rendahnya tingkat pendidikan di Indonesia.

Faktor-faktor tersebut menyebabkan tingkat pendayagunaan tenaga kerja Indonesia juga relatif rendah yang tercermin pada kecilnya proporsi penduduk yang bekerja, tingginya tingkat pengangguran dan setengah pengangguran serta rendahnya tingkat produktivitas dan penghasilan keluarga. Besarnya beban pengangguran ini memperburuk tingkat kemiskinan, karena bagi mereka yang bekerja masih diharapkan pada minimnya rata-rata Upah Minimum Provinsi (UMP) yang ternyata di seluruh Indonesia masih tergolong relatif rendah.

Pada dasarnya, negara kita memberikan jaminan atas penghidupan yang layak bagi warga negaranya melalui Undang-Undang Dasar Negara Republik Indonesia Tahun 1945 yaitu:

Pasal 28 C (1)

"Setiap orang berhak mengembangkan diri melalui pemenuhan kebutuhan dasarnya, berhak mendapat pendidikan dan memperoleh manfaat dari ilmu pengetahuan dan teknologi, seni dan budaya, demi meningkatkan kualitas hidupnya dan demi kesejahteraan umat manusia." 
Ketentuan Pasal 28 C (1) ini didukung dengan Undang-Undang Nomor 13 Tahun 2003 tentang Ketenagakerjaan yang secara khusus memberikan kebebasan kepada warga negaranya untuk bekerja di dalam maupun di luar negeri. Kebebasan ini diakomodir di dalam Undang-Undang Nomor 13 Tahun 2003 tentang Ketenagakerjaan dengan adanya ketentuan yang menyatakan bahwa setiap tenaga kerja mempunyai hak dan kesempatan yang sama untuk memilih, mendapatkan atau pindah pekerjaan dan memperoleh penghasilan yang layak di dalam atau luar negeri.

Penempatan TKI untuk dapat bekerja di luar negeri adalah bentuk nyata upaya memberikan dan mewujudkan hak dan kesempatan yang sama bagi tenaga kerja untuk mendapatkan pekerjaannya.

Isu utama yang berkenaan dengan TKI ke luar negeri adalah masih tingginya migran tanpa dokumen yang sah (illegal), yang menyebabkan timbulnya berbagai masalah yang menyangkut perlindungan tenaga kerja.

Beberapa potret kasus kekerasan yang terjadi pada TKI dapat dilihat secara jelas sejak tahun 2004 bulan Mei, dimana media massa gencar memberitakan tentang penganiayaan yang dialami oleh Nirmala Bonat, seorang PRT yang bekerja di Malaysia. Ia mengalami penyiksaan dari majikannya berupa penyiraman air panas, bekas setrika pada badannya, pemukulan kepala dengan gantungan baju oleh majikannya dan pemukulan cawan pada kepala Nirmala Bonat. Meski demikian, bukalah berarti bahwa kejadian penganiayaan terhadap TKI baru terjadi pada kisaran tahun 2004. Tentu sudah banyak terjadi penganiayaan namun tidak diketahui oleh masyarakat Indonesia secara umum. Kasus tindak kekerasan terhadap TKI menjadi pembicaraan khalayak umum dan mulai terekspose secara ramai di berbagai media massa, karena baru pada tahun 2004 itulah Indonesia memiliki Undang-Undang Nomor 39 Tahun 2004 tentang Penempatan dan Perlindungan TKI di Luar Negeri yang dibentuk pada masa pemerintahan Megawati.

Selain Nirmala Bonat, tindak kekerasan juga dialami oleh Ceriyati pada kisaran tahun 2007 dan Siti Hajar di tahun 2009. Keduanya merupakan PRT yang bekerja di Malaysia. Siti Hajar disiksa oleh majikan dengan menggunakan air panas, martil dan gunting. Ceriyati mengalami pemukulan dan pelarangan beribadah oleh majikannya. Selain itu, ia juga tidak mendapatkan gaji selama beekrja empat setengah bulan di rumah majikannya (Azmy, 2012:7).

Angka pengangguran tinggi, pemutusan hubungan kerja (PHK), rendahnya pendidikan, sempitnya lapangan kerja yang tersedia di dalam negeri menjadi latar belakang maraknya minat masyarakat untuk menjadi TKI dengan iming-iming penghasilan yang lebih besar berkali lipat di luar negeri. Karena faktor inilah, ditambah juga faktor pengiriman TKI yang tidak terdidik menyebabkan pengiriman TKI mengalami banyak permasalahan, salah satunya yaitu penyiksaan terhadap TKI kita di luar negeri.

Banyaknya tenaga kerja yang tidak mampu tertampung dalam kesempatan kerja yang terbatas di dalam negeri, merupakan potensi yang dapat disalurkan dan ditempatkan ke luar negeri. Pihak-pihak yang terkait dengan pelaksanaan 
penempatan tenaga keja ke luar negeri terdiri dari calon tenaga kerja yang hendak bekerja di luar negeri, pelaksana penempatan TKI (tenaga kerja Indonesia) swasta yang berbentuk Perseroan terbatas (PT) dan memiliki izin dari Menteri Tenaga Kerja, mitra usaha dan pengguna jasa TKI (tenaga kerja Indonesia). Menurut Undang-Undang Nomor 39 Tahun 2004 tentang Pelaksana penempatan TKI di Luar Negeri pengertian pihak-pihak yang terkait tersebut adalah:

a. Calon Tenaga Kerja Indonesia atau disebut calon TKI adalah setiap warga negara Indonesia yang memenuhi syarat sebagai pencari kerja yang akan bekerja di luar negeri dan terdaftar di instansi Pemerintah Kabupaten/kota yang bertanggung jawab di bidang ketenagakerjaan;

b. Pelaksana penempatan TKI swasta adalah badan hukum yang memperoleh izin tertulis dari Pemerintah untuk menyelenggarakan pelayanan penempatan TKI di luar negeri;

c. Mitra usaha adalah instansi atau badan usaha berbentuk badan hukum di negara tujuan yang bertanggung jawab menempatkan TKI pada Pengguna;

d. Pengguna Jasa TKI adalah instansi pemerintah, Badan Hukum Pemerintah, Badan Hukum Swasta, dan/atau Perseorangan di negara tujuan yang mempekerjakan TKI.

Pelaksana penempatan TKI swasta yang akan menempatkan TKI ke luar negeri harus terlebih dahulu membuat Perjanjian Kerja Sama Penempatan yang dibuat secara tertulis dengan Mitra Usaha atau Pengguna yang memuat hak dan kewajiban masing-masing pihak. Hal ini sangat penting bagi calon TKI tentang adanya jaminan kepastian penempatan yang akan dilakukan oleh pelaksana penempatan TKI dengan mitra usaha atau pengguna jasa TKI di luar negeri (Abdurrahman, 2006: 33).

Calon TKI juga harus membuat perjanjian penempatan TKI secara tertulis antara pelaksana penempatan TKI swasta dengan calon TKI yang memuat hak dan kewajiban masing-masing pihak dalam rangka penempatan TKI di negara tujuan sesuai dengan Pengguna jasa membuat Perjanjian Kerja yang memuat syarat-syarat kerja, hak dan kewajiban masing-masing pihak (Abdurrahman, 2006: 33).

Penempatan TKI ke luar negeri sebagian besar masih terbatas pada sektor informal. Hal ini antara lain disebabkan oleh kualitas tenaga kerja yang tersedia masih relatif rendah. Permasalahan yang muncul ke permukaan adalah tidak adanya perlindungan bagi para TKI yang dilatarbelakangi oleh, misalnya, PJTKI sebagai pelaksana penempatan tenaga kerja ke luar negeri lebih berorientasi bisnis sehingga lebih mementingkan untuk mendapatkan keuntungan sebesar-besarnya dan sering mengorbankan kepentingan pekerjanya. Dinas terkait (dalam hal ini yaitu Dinas Tenaga Kerja di kabupaten/kota) sering tidak terlibat dalam proses rekruitmen karena rekruitmen banyak dilakukan oleh para calo yang langsung mencari sumber calon TKI di pedesaan, sedangkan kelengkapan adminstrasi dapat dengan mudah diperoleh di tempat lain. Permasalahan lainnya adalah koordinasi pembinaan penempatan TKI lintas sektor kurang berjalan dan kurang harmonis, sebagai contoh 
dalam pemberian visa kerja sering tidak memperhatikam kelengkapan persyaratan seperti adanya job-order dan sertifikasi dari calon TKI (Saleh, 2005: 33).

Selain itu, banyak oknum yang memanfaatkan ketidakberdayaan TKI untuk kepentingannya, baik saat rekruitmen, pelatihan di penampungan, maupun saat kepulangannya (Saleh, 2005: 33). Semua masalah tersebut merupakan faktor-faktor yang melatarbelakangi maraknya penyiksaan fisik yang diterima oleh para TKI kita di negeri orang.

2. Peranan Keberadaaan Undang-Undang Nomor 34 Tahun 2004 tentang Penempatan dan Perlindungan Tenaga Kerja Indonesia di Luar Negeri Dalam Melindungi Para TKI di Luar Negeri.

Tujuan perlindungan tenaga kerja adalah untuk menjamin keberlangsungan sistem hubungan kerja secara harmonis tanpa disertai adanya tekanan dari pihak yang kuat kepada pihak yang lemah. Oleh sebab itu, pengusaha wajib melaksanakan ketentuan perlindungan tenaga kerja tersebut sesuai peraturan perundangundangan yang berlaku (Khakim, 2014: 99). Salah satu dasar hukum perlindungan tenaga kerja adalah Undang-Undang Nomor 13 Tahun 2003 tentang Ketenagakerjaan serta Undang-Undang Nomor 39 Tahun 2004 tentang Penempatan dan Perlindungan Tenaga Kerja Indonesia di Luar Negeri.

Pada dasarnya, negara telah menjamin hak-hak warga negaranya melalui Undang-Undang Dasar Tahun 1945 Bab X A Hak Asasi Manusia, khususnya pasalpasal sebagai berikut:

a. Pasal 28A;

"Setiap orang berhak untuk hidup serta berhak mempertahankan hidup dan kehidupannya."

b. Pasal 28 I (1)

"Hak untuk hidup, hak untuk tidak disiksa, hak kemerdekaan pikiran dan hati nurani, hak beragama, hak untuk tidak diperbudak, hak untuk diakui sebagai pribadi di hadapan hukum, dan hak untuk tidak dituntut atas dasar hukum yang berlaku surut adalah hak asasi manusia yang tidak dapat dikurangi dalam keadaan apa pun."

Menurut Soepomo dalam Asikin, perlindungan tenaga kerja dibagi menjadi tiga macam, yaitu (Asikin, 1993: 76):

a. Perlindungan ekonomis;

Yaitu perlindungan tenaga kerja dalam bentuk penghasilan yang cukup, termasuk bila tenaga kerja tidak mampu bekerja di luar kehendaknya.

b. Perlindungan sosial;

Yaitu perlindungan tenaga kerja dalam bentuk jaminan kesehatan kerja dan kebebasan berserikat dan perlindungan hak untuk berorganisasi.

c. Perlindungan teknis;

Yaitu perlindungan tenaga kerja dalam bentuk keamanan dan keselamatan kerja. 
Sejalan dengan semakin meningkatnya tenaga kerja yang ingin bekerja di luar negeri dan besarnya jumlah TKI yang sekarang ini bekerja di luar negeri, meningkat pula kasus perlakuan yang tidak manusiawi terhadap TKI di luar negeri. Kasus yang berkaitan dengan nasib TKI semakin beragam bahkan berkembang ke arah perdagangan manusia yang dapat dikategorikan sebagai kejahatan kemanusiaan (Abdurrahman, 2006: 32).

Secara etimologis, Hak Asasi Manusia (HAM) terbentuk dari tiga (3) suku kata, yaitu kata hak, kata asasi dan kata manusia. Kata hak dan kata asasi berasal dari Bahasa Arab, sedangkan kata manusia berasal dari Bahasa Indonesia. Kata haqq adalah bentuk tunggal dari kata huqûq. Kata haqq diambil dari akar kata haqqa, yahiqqu, haqqan, yang artinya benar, nyata, pasti, tetap, dan wajib. Apabila dikatakan yahiqqu 'alaika an taf'ala kadzâ. (Milton, 2008: 17). Berdasarkan kata tersebutlah, haqq diartikan kewenangan atau kewajiban untuk melakukan sesuatu. Sedangkan kata asasi berarti dasar atau pokok (Moelino, 1994: 60).

HAM merupakan hak-hak yang diberikan langsung oleh Tuhan Yang Maha Pencipta (hak-hak yang bersifat kodrati). Karena itu tidak ada kekuasaan apa pun di dunia yang dapat mencabutnya. HAM juga diartikan sebagai hak-hak mendasar pada diri manusia. Istilah ini mempunyai perbedaan dalam penyebutannya, tetapi mempunyai makna yang sama (Muhtaj, 2008: 17-18).

Menurut John Locke, tidak semua hak yang dimiliki oleh manusia harus diserahkan kepada pihak lain, melainkan hanya hak-hak yang berhubungan dengan perjanjian negara saja yang diserahkan, sedangkan sisanya tetap berada pada diri masing-masing warga negara (individu). Sebagaimana menurut John Locke (Sunggono dan Harianto, 2009: 75-76):

"men being by nature all free, equal and independent, no one can be put out of this estate, and subjected to the political power of another without his own consent, which other men to join and unite into a community for their comfortable, safe and peaceable, living one amongst another ..."

Dari beberapa tindakan yang berupa kejahatan HAM termasuk juga masalah penyiksaan. Secara umum, tindak pidana terhadap tubuh pada KUHP disebut "penganiayaan". Dibentuknya pengaturan tentang kejahatan terhadap tubuh manusia ini dutujukan bagi perlindungan kepentingan hukum atas tubuh dari perbuatan-perbuatan berupa penyerangan atas tubuh atau bagian dari tubuh yang mengakibatkan rasa sakit atau luka, bahkan karena luka yang sedemikian rupa pada tubuh dapat menimbulkan kematian.

Penganiayaan dalam Kamus Besar Bahasa Indonesia dimuat arti sebagai "perilaku yang sewenang-wenang". Pengertian tersebut dalam arti luas termasuk yang menyangkut "perasaan" atau "batin". Mengenai penganiayaan dalam Pasal 351 KUHP, R. Soesilo mengatakan bahwa undang-undang tidak memberi ketentuan apakah yang diartikan dengan "penganiayaan" itu (Soesilo, 1991). Secara yurisprudensi, yang diartikan dengan "penganiayaan" yaitu sengaja menyebabkan perasaan tidak enak (penderitaan), rasa sakit, atau luka. Menurut alinea 4 pasal ini, 
masuk pula dalam pengertian penganiayaan ialah "sengaja merusak kesehatan orang".

R. Soesilo juga memberikan contoh dengan apa yang dimaksud dengan "perasaan tidak enak", "rasa sakit", "luka", dan "merusak kesehatan" (Soesilo, 1991 :86):

a. "perasaan tidak enak" misalnya mendorong orang terjun ke kali sehingga basah, menyuruh orang berdiri di terik matahari, dan sebagainya.

b. "rasa sakit" misalnya menyubit, mendupak, memukul, menempeleng, dan sebagainya.

c. "luka" misalnya mengiris, memotong, menusuk dengan pisau dan lain-lain.

d. "merusak kesehatan" misalnya orang sedang tidur, dan berkeringat, dibuka jendela kamarnya, sehingga orang itu masuk angin.

Untuk itulah setelah melalui proses yang panjang akhirnya terbitlah UndangUndang Nomor 39 Tahun 2004 tentang Penempatan dan Perlindungan TKI di Luar Negeri. Negara wajib secara aktif menjamin dan melindungi hak asasi warga negara yang bekerja baik di dalam maupun di luar negeri berdasarkan prinsip persamaan hak, demokrasi, keadilan sosial, kesetaraan gender, serta anti perdagangan manusia.

Akan tetapi sangat disayangkan sekali, karena pada faktanya Undang-Undang Nomor 39 Tahun 2004 tentang Penempatan dan Perlindungan TKI di Luar Negeri yang pada dasarnya adalah payung hukum bagi para TKI kurang tegas melindungi dan menjamin merek di negeri orang.

Tidak hanya pemerintah yang perlu disoroti, TKI pun juga harus disadarkan akan kewajiban, hak, serta hukum yang berlaku agar mereka dapat melindungi diri mereka. Pada realitanya, hukum selalu berpihak kepada penguasa. Banyak peraturan hukum yang berlaku, tidak dapat berjalan dikarenakan (Soesilo, 1991: 107-109):

a. Hukum tidak akrab dengan realitas sosial, tidak sesuai dengan cita-cita keadilan rakyat karena bahasa hukum sangat berbelit dan sulit untuk dimengerti sehingga multi tafsir;

b. Peraturan hukum harus disertai dengan peraturan pelaksana dari peraturan hukum (undang-undang). Banyak peraturan hukum yang tidak dapat dilaksanakan, karena tidak disertai peraturan pelaksana, kalaupun ada peraturan pelaksana tersebut tidak dapat berjalan, karena tidak ada sinergitas antara peraturan hukum yang dibuat dengan peraturan pelaksana sebagai acuan operasionalnya.

Oleh sebab itulah dibutuhkan sebuah komunikasi hukum. Maksudnya adalah mekanisme yang menghubungkan antara manusia, mengembangkan semua lambang dari pikiran bersama dengan arti yang menyertainya dan melalui keleluasaan yang menyediakan tepat pada waktunya. Komunikasi juga merupakan penyampaian pengertian antar individu (Tommy dan Fahrianoor, 2004: 2; Moor, 1993: 78).

Bentuk nyata dari komunikasi hukum yang dibangun adalah melalui penyuluhan, sebagai cara atau usaha pendidikan yang sifatnya non formal. 
Penyuluhan dapat dipersepsikan sebagai pendidikan non formal, tentu saja implementasinya bukan saja untuk hukum, akan tetapi dapat diterapkan pada aktivitas lainnya yang berkaitan pemberian pengetahuan kepada orang lain (Samsudin, 1997: 1). Melalui penyuluhan harus dapat disosialisasikan kepada khalayak bahwa kaidah-kaidah baru memang penting untuk diperhatikan agar seseorang tidak mengalami kesulitan di tengah kehidupan baru yang tertib, yang disebut kehidupan bernegara (Soetandyo, 2002: 373). Pada konteks komunikasi dalam proses pembangunan memainkan peranan penting yaitu (Tommy dan Fahrianoor, 2004: 8-12):

a. Memberikan informasi kepada masyarakat;

b. Komunikasi berperan menumbuhkan keinginan untuk mengadakan perubahan dan penerimaan suatu gagasan baru.

Komunikasi hukum merupakan persyaratan pokok dari sebuah sistem hokum (Friedman, 1997: 56). Tidak ada seorang pun dapat berperilaku menurut atau sesuai hukum apabila ia tidak mengetahui isi atau yang diatur oleh hukum itu. Komunikasi hukum mempunyai tujuan tertentu yang diharapkan, yaitu untuk menciptakan pengertian bersama agar terjadi perubahan pikiran, sikap atau perilaku.

Pahlawan devisa negara kita, TKI di manapun ia berada, tetap memiliki perlindungan akan hak-haknya yang sama dengan mereka yang bekerja di dalam negeri tanpa terkecuali. Adanya Undang-Undang Nomor 39 Tahun 2004 tentang Penempatan dan Perlindungan Tenaga Kerja Indonesia di Luar Negeri perlu didukung pula dengan:

a. Kemampuan berbahasa memadai;

Salah satu faktor yang menyebabkan terjadinya penganiayaan dan penyiksaan terhadap TKI di negara orang adalah persoalan bahasa. Sebagian besar para TKI yang diberangkatkan dalam kondisi kepahaman bahasa yang minim. Hal ini jelas akan menjadi faktor penghambat komunikasi antara seorang pekerja dengan majikan. Oleh sebab itu, hal penting yang harus dipenuhi seorang TKI yang akan diberangkatkan adalah persoalan bahasa, bahasa harus dikuasai sebab merupakan kunci utama dalam komunikasi.

b. Kemampuan mengenal budaya negara yang akan dituju;

Kemampuan membaca dan memahami budaya suatu daerah merupakan modal penting untuk seseorang dapat hidup di daerah bersangkutan. Kesalahan dalam memahami sebuah budaya bukan hanya akan menghambat komunikasi, namun lebih parah lagi dapat mengancam keselamatan dirinya. Penyiksaan TKI di luar negeri salah satunya disebabkan oleh ketidaktahuan para TKI terhadap budaya dan adat istiadat suatu daerah.

c. Kemampuan intelektualitas;

Daya intelektual dan wawasan yang dimiliki oleh seseorang akan menjadi faktor bagaimana orang lain akan bersikap terhadap kita. TKI di luar negeri 
yang kerap mendapat penyiksaan dan penganiayaan fisik, mayoritas berasal dari tenaga kerja non terdidik. Biasanya, berasal dari kalangan pekerja rumah tangga yang kebanyakan kaum wanita. Perspektif negaranegara maju memandang Indonesia adalah sebuah negara besar yang masih miskin dan dilanda persoalan dalam negeri yang tak kunjung putus.

Kebijakan perlindungan terhadap TKI belum dapat memberikan perlindungan secara optimal terhadap kaum TKI. Perlindungan yang minim pada tahapan pra penempatan ditandai oleh banyaknya rekruitmen massif oleh para calo yang minim melakukan sosialisasi informasi, pemalsuan dokumen, dan pengeluaran biaya yang banyak, serta koordinasi dengan instansi terkait yang tidak kuat. Pada tahap penempatan, tidak adanya upah minimum dan izin cuti libur sebagai hak sosial TKI juga merupakan bentuk kekerasan ekonomi dan psikis. Sedangkan pada tahapan purna penempatan, masih ada pembayaran oleh TKI yang tidak jelas alokasinya di Terminal 4 atau Gedung Pendataan Kepulangan TKI (GPKTKI) (Azmy, 2012: 192).

\section{KESIMPULAN DAN SARAN}

\section{Kesimpulan}

Maraknya TKI yang mendapatkan perlakuan buruk atau penyiksaan di negeri orang menimbulkan berbagai tanda tanya apa sebenarnya faktor pemicu TKI kita sampai diperlakukan sedemikian buruk. Faktor-faktor umum berupa tingkat kesejahteraan sosial yang rendah di Indonesia serta sempitnya lapangan pekerjaan yang ada menyebabkan meledaknya minat untuk menjadi TKI, ditambah minim atau rendahnya kualitas TKI kita sehingga tidak dapat dipungkiri menjadi TKI ilegal pun dijalani oleh sebagian besar mereka. Berbagai pemberitaan media yang menyorot penyiksaan TKI semakin menjelaskan bahwa keberadaan Undang-Undang Nomor 39 Tahun 2004 tentang Penempatan dan Perlindungan TKI di Luar Negeri dalam memberikan jaminan perlindungan TKI masih sangat jauh dari harapan.

Keberadaan Undang-Undang Nomor 39 Tahun 2004 tentang Penempatan dan Perlindungan TKI di Luar Negeri dalam memberikan jaminan perlindungan bagi TKI juga harus didukung dengan upaya dari TKI itu sendiri untuk mempersiapkan diri mereka sebaik-baiknya sebelum benar-benar bekerja di luar negeri. Hal ini tidak lain tidak bukan, merupakan upaya preventif (pencegahan) untuk meminimalisir terjadinya penyiksaan baik ringan, sedang, maupun berat terhadap mereka. Selain itu, semua pihak-pihak terkait yaitu TKI itu sendiri, pelaksana penempatan TKI, mitra usaha, dan pemerintah harus saling bahu-membahu serta saling menyadari akan kewajibannya masing-masing agar perlindungan hukum bagi TKI sejak proses persiapan penempatan, selama penempatan, hingga pulang kembali, TKI di luar negeri dapat lebih terjamin serta terlindungi.

2. Saran

\section{a. Terhadap Pemerintah}

1) Agar pemerintah dapat melibatkan calon TKI di dalam pembentukan kebijakan dalam rangka memberikan perlindungan hukum bagi para calon TKI. 
2) Agar pemerintah dapat lebih cermat dan tegas di dalam membentuk suatu kebijakan-kebijakan dalam rangka memberikan perlindungan hukum bagi para calon TKI.

3) Agar pemerintah lebih dapat berbenah dan dapat mengevaluasi kebijakan yang ada dengan melihat dari maraknya kejadian penyiksaan yang terjadi terhadap para TKI di luar negeri .

4) Agar pemerintah dapat memberikan bekal pengetahuan yang cukup bagi para calon TKI untuk menghindarkan diri calon TKI dari kejadiankejadian yang tidak diinginkan.

\section{b. Terhadap Calon TKI}

1) Agar calon TKI dapat lebih berpartisipasi aktif dalam penyusunan kebijakan perlindungan hukum bagi para calon TKI.

2) Agar calon TKI lebih sadar akan pentingnya mengikuti proses rekruitmen yang legal sesuai dengan ketentuan dan prosedur yang berlaku.

3) Agar calon TKI dapat lebih berpartisipasi aktif dalam mencari bekal pengetahuan yang cukup untuk menghindarkan dirinya dari berbagai kemungkinan terjadinya kejadian-kejadian yang tidak diinginkan.

\section{DAFTAR PUSTAKA}

\section{A. BUKU DAN JURNAL}

Abdurrahman, Muslan (2006). Ketidakpatuhan TKI Sebuah Efek Diskriminasi Hukum. Malang: UMM Press.

Asikin, Zainal (1993). Dasar-Dasar Hukum Perburuhan. Jakarta: PT Rajagrafindo Persada.

Azmy, Ana Sabhana (2012). Negara dan Buruh Migran Perempuan. Jakarta: Buku Obor.

Bakir, Zainab dan Manning, Chris (1984). Angkatan Kerja di Indonesia, Jakarta: CV Rajawali.

Friedman (1997). The Legal System : a Social Science Perspective. Russel Sage Foundation.

Khakim, Abdul (2014). Dasar-Dasar Hukum Ketenagakerjaan Indonesia. Bandung: PT Citra Aditya Bakti.

Lluch dan Mazumdar (1981). Wages and Employment in Indonesia, Squire, Lyn Washington, World Bank.

Moelino, Anton M (1994). Kamus Besar Bahasa Indonesia, Jakarta: Balai Pustaka.

Milton, J. (1979). A Dictionary of Modern Written Arabic. Wiebaden, Oto Harrassowitz.

Moor, Fazier (1993). Hubungan Masyarakat, Prinsip, Kasus dan Masalah, Bandung: Rosdakarya.

Muhtaj, Majda El (2008). Dimensi-Dimensi HAM Mengurai Hak Ekonomi, Sosial dan Budaya. Jakarta: Raja Grafindo Persada. 
Saleh, Harry Heriawan (2005). Persaingan Tenaga Kerja Dalam Era Globalisasi (Antara Perdagangan dan Migrasi). Jakarta: Pustaka Sinar Harapan.

Samsudin (1977). Dasar-Dasar Penyuluhan dan Modernisasi Pertanian. Bandung: Bina Cipta.

Soetandyo W (2002). Hukum, Paradigma, Metode dan Dinamika Masalahnya. Jakarta: Huma.

Sunggono, Bambang dan Harianto, Aries. Bantuan Hukum dan Hak Asasi Manusia. Bandung: Mandar Maju.

Tommy dan Fahrianoor (2004). Komunikasi Penyuluhan Dalam teori dan Praktek, Arti Bumi Intaran.

United Nations, Patterns of urban and rural population growth, New York, United Nations, Departement of Economic and Social Affairs, Population Studies series No. 68 ST/ESA/SER.A.68.

Usman, Hardius dan Djalal, Nachrowi (2004). Pekerja Anak di Indonesia (Kajian Kuantitatif). Jakarta: PT Gramedia Widiasarana Indonesia.

Tjandraningsih, Pekerja Anak : Hak Sebagai Anak VS Hak Sebagai Pekerja, Jurnal Analisis Sosial, Edisi No. 5 Mei 1997

\section{B. Undang-Undang}

Undang-Undang Nomor 13 Tahun 2003 tentang Ketenagakerjaan.

Undang-Undang Nomor 39 Tahun 2004 tentang Penempatan dan Perlindungan Tenaga Kerja Indonesia di Luar Negeri.

Kitab Undang-Undang Hukum Pidana (KUHP). 